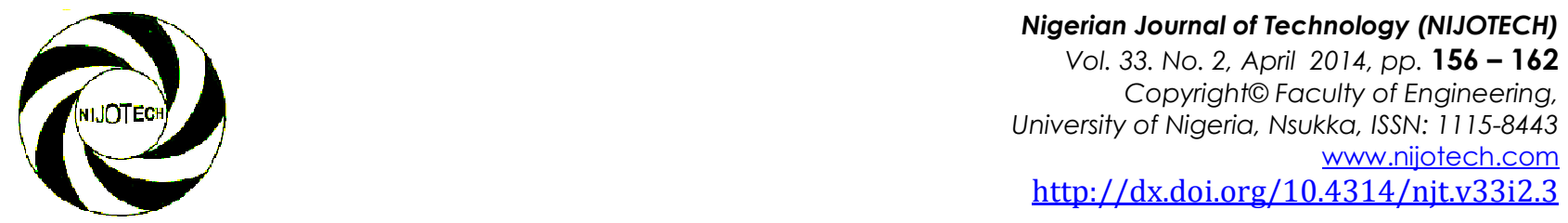

\title{
A COMPARISON OF BOND PERFORMANCE OF CONCRETE REINFORCED WITH REINFORCEMENTS FROM DIFFERENT MANUFACTURERS
}

\author{
A. Oyelade ${ }^{1}$, C. Fapohunda $2,{ }^{*}, 0$. Adewusi $^{3}$ \\ 1,3 DEPARTMENT OF Civil AND ENVIRONMENTAL ENGINEERING, UNIVERSITY OF LAGOS, NIGERIA \\ 2DEPARTMENT OF BUILDING, CALEB UNIVERSITY, IMOTA LAGOS, NIGERIA
}

E-mail Addresses.1 oyeladeakintoye@yahoo.com2 fapohunda07@yahoo.com,3phemmine@yahoo.com

\begin{abstract}
The transfer of stress from a deformed bar to the concrete is achieved by mechanical locking of the steel into the surrounding concrete. This interfacial bond strength between steel and the surrounding concrete is an important factor influencing the strength and durability of reinforced concrete structure. This paper presents the result of investigation conducted to find out the bond performance of reinforcement from different manufacturer. $12 \mathrm{~mm}$ and $16 \mathrm{~mm}$ diameter steel specimens from five different manufacturers were used for this investigation. Tensile properties and pull out test were conducted. The results showed that: (i) all the steel specimens substantially met the minimum requirement specified by relevant standards for both $12 \mathrm{~mm}$ and $16 \mathrm{~mm}$ diameters, (ii) bond performance of locally-made was found to be better than the imported ones for $12 \mathrm{~mm}$ diameter, but for $16 \mathrm{~mm}$ diameter, imported steel showed a better bond performance than the locally made ones, (iii) all the steel specimens exhibited splitting failure, (iv) the lowest values of slippage were exhibited by a locally-sourced steel specimens, and $(\mathrm{V})$ bond stresses obtained from this investigation for both $12 \mathrm{~mm}$ and $16 \mathrm{~mm}$ diameter bars are structurally adequate.
\end{abstract}

Keywords: Bond strength, Concrete, Failure Load, Pull-out Test, and Reinforcement.

\section{INTRODUCTION}

Reinforced concrete structures may have to fulfil functions that go beyond withstanding the imposed load. For example cracking or deflection pattern of the structure may be critical than the strength criteria. The capacity for the composite structures to adequately function monolithically within the structures determines the expected strength of the structure. Thus, characterizing the crack evolution (opening, width and spacing) are thus key points in the evaluation of structural adequacy of reinforced concrete structures [1]. It has been established by [2] that for reinforced concrete to function effectively as a composite material it is important for the reinforcing steel to be bonded to the surrounding concrete. The mechanics of bond stress transfer between reinforcement and concrete has been investigated by [3] and [1]. The term bond is defined as the resistance against slip between steel and surrounding concrete and it is essentially composed of three components: chemical adhesion, friction and mechanical interaction between the ribs of the bar and concrete. Reinforcing bar diameter had very important effect on the bond strength. In the investigation conducted by [4], it was reported that high strength concrete provided about $80 \%$ higher bond strength with $10 \mathrm{~mm}$ diameter reinforcement steel than that of normal strength concrete with same size reinforcement, whilst with 25 $\mathrm{mm}$ diameter steel reinforcement, the difference dropped to $30 \%$ indicating the influence of reinforcement size and concrete quality on the bond strength. The susceptibility of reinforcement to corrosion, with attendant weakening effect on bond strength due to loss of adhesion, has made researchers develop different methods of protecting the steel bars with steel fibre reinforced polymer (FRP), sand coating, epoxy coating etc. [5, 6, and 7]. Also, many expressions have been developed for bond stress. According to [8] the bond stress acting on 
reinforcement $u$ can be expressed as the change in the stress in the reinforcement over the length $d x$ as

$$
\begin{aligned}
& u\left(\pi d_{b} d x\right)=A_{b}\left(f_{s}+d f_{s}\right)-A_{b} f_{s} \\
& u=4 A_{b} d f_{s} d x=\pi d_{b}{ }^{2} d f_{s} d x
\end{aligned}
$$

For uniform bond within the concrete,

$$
u=\frac{F_{\max }}{\pi d L}
$$

Where $F_{\max }$ is the maximum pull out load, $d$ is the diameter of the bar, and $L$ the embedded bar length.

According to [9] bond stress can be expressed as:

$$
u=0.083045 \sqrt{f_{c}}\left[1.2+3 \frac{c}{d_{b}}+50 \frac{d_{b}}{L_{d}}\right]
$$

where $\mathrm{c}=$ minimum concrete cover, $\mathrm{mm}$ and $\mathrm{f}_{\mathrm{c}}$ is the concrete compressive strength $(\mathrm{MPa}), \mathrm{d}_{\mathrm{b}}=$ bar diameter, and $\mathrm{L}_{\mathrm{d}}=$ embedded length in concrete.

This was modified by [10] is:

$$
\begin{aligned}
u=0.083045 \sqrt{f_{c}} & {\left[\left(1.06+2.12 \frac{c}{d_{b}}\right)(0.92\right.} \\
+ & \left.\left.0.08 \frac{C_{\max }}{C_{\min }}\right)+75 \frac{d_{b}}{L_{d}}\right]
\end{aligned}
$$

Where $\mathrm{C}_{\min }=\min \left(\mathrm{C}_{\mathrm{x}}, \mathrm{C}_{\mathrm{y}}, \frac{C_{s}}{2}\right)$ and $\mathrm{C}_{\max }=\max$ $\left[\min \left(C_{x}, \frac{C_{s}}{2}\right) C_{y}\right], \mathrm{C}_{\mathrm{x}}=$ the side cover, $\mathrm{C}_{\mathrm{y}}=$ the bottom cover, and $\mathrm{C}_{\mathrm{s}}=$ the spacing between the bars.

For high strength concrete of compressive $\geq 50 \mathrm{~N} / \mathrm{mm}^{2}$, [11] proposed an equation of the form:

$$
u=8.6\left[\frac{C / d_{b}+0.5}{C / d_{b}+5.5}\right] f_{c t}
$$

where $\mathrm{C}=$ the minimum cover, $\mathrm{f}_{\mathrm{ct}}$ the tensile strength of concrete taken as $0.55 \sqrt{\mathrm{f}_{\mathrm{c}}}$, in MPa.

Some national standards also developed expression for bond stress. For example, the [12] expressed the bond stress as:

$$
u=0.265 \sqrt{f_{c}}\left[\frac{c}{d_{b}}+0.5\right]
$$

Where $d=$ diameter of the bar, $c=$ the cover, $\mathrm{f}_{\mathrm{c}}=$ compressive strength

Also [13] expressed the bond stress as:

$$
u=\beta \sqrt{f_{c u}}
$$

In his investigation, [3] had obtained an expression of the form in equation 9

$u=$

$0.083045 \sqrt{f_{c}}\left[22.8-0.208 \frac{c}{d_{b}}-\right.$

$$
\left.38.212 \frac{d_{b}}{L_{d}}\right]
$$

where $\mathrm{c}=$ minimum concrete cover, $\mathrm{mm}$ and $\mathrm{f}_{\mathrm{c}}$ is the concrete compressive strength $(\mathrm{MPa}), \mathrm{d}_{\mathrm{b}}=$ bar diameter, and $\mathrm{L}_{\mathrm{d}}=$ embedded length in concrete.

Steel used as reinforcement in some developing counties are a combination of imported steel and locally manufactured steel. The locally manufactured steel companies use metal scraps like re-cycled obsolete vehicle, machine parts, etc. There is however a growing concern about the bond performance of steel that are manufactured from metal scraps (recycle obsolete vehicle and machine parts) as reinforcing steel in concrete. This is because there is presently little knowledge on their mechanics of bond strength. Thus the aim of this investigation is to determine the bond characteristics of steel reinforcement obtained from different manufacturers, and subsequently compare them, with a view to determining their adequacy for structural application, using Nigeria as a case study.

\section{EXPERIMENTAL PROGRAM}

\subsection{Materials}

In order to carry out this investigation, five samples of steel bars were used. This consists of three samples of local steel bars obtained from three different manufacturer and named $\mathrm{L}_{1}, \mathrm{~L}_{2}$, and $\mathrm{L}_{3}$, in addition to

\begin{tabular}{|c|c|c|}
\hline S/no. & Label & Source \\
\hline 1 & $\mathrm{~L}_{1}$ & $\begin{array}{l}\text { Steel manufactured in Nigeria from } \\
\text { metal scraps from re-cycle obsolete } \\
\text { vehicle and machine parts }\end{array}$ \\
\hline 2 & $\mathrm{~L}_{2}$ & $\begin{array}{l}\text { Steel manufactured in Nigeria from } \\
\text { metal scraps from re-cycle obsolete } \\
\text { vehicle and machine parts }\end{array}$ \\
\hline 3 & $\mathrm{~L}_{3}$ & $\begin{array}{l}\text { Steel manufactured in Nigeria from } \\
\text { metal scraps from re-cycle obsolete } \\
\text { vehicle and machine parts }\end{array}$ \\
\hline 4 & $\mathrm{~F}_{1}$ & $\begin{array}{l}\text { Billet from Ukraine but manufactured } \\
\text { in Nigeria }\end{array}$ \\
\hline 5 & $\mathrm{~F}_{2}$ & Imported from Russia \\
\hline
\end{tabular}
two imported steels were sourced externally. One of the externally sourced steel specimens was manufactured by a company based in Nigeria, but with imported billet from Ukraine, and the second was directly imported from Russia. They are named $F_{1}$ and $\mathrm{F}_{2}$. The summary of the source of the reinforcement used for this investigation is presented in Table 1.

\section{Table 1: Description of the Source of Reinforcement} Used for this Investigation

Two different bar diameters of $12 \mathrm{~mm}$ and $16 \mathrm{~mm}$ were used for this investigation. The cement is the ordinary Portland which conforms to [14 and 15]. The fine aggregates used in this research study was River Sand obtained from Ogun River located at Ogun State. The particle sizes of sand were those passing through 
sieve with aperture size of $3.35 \mathrm{~mm}$ but retained on sieves of $63 \mu \mathrm{m}$ and having a bulk density of 1540 $\mathrm{kg} / \mathrm{m}^{3}$. It was confirmed to be salt free and free from deleterious substances. The coarse aggregates were obtained from crushed stone at a quarry with particle size range between $10-20 \mathrm{~mm}$. Both the fine and coarse aggregates were free from dirt, silt, clay and other deleterious materials. The water used was potable water.

\subsection{Experimental Investigations}

\subsubsection{Tensile Test}

Tensile strength of reinforcing bars diameters $12 \mathrm{~mm}$ and $16 \mathrm{~mm}$ were tested for each sample (a total of 30 specimens). The test specimens were cut to a length of $600 \mathrm{~mm}$. Two points are marked on each specimen, $150 \mathrm{~mm}$ to the left and right of the mid-point of the specimen to produce three clear spans of $200 \mathrm{~mm}$ along the length of the specimens. The test specimens were placed one after the other into the machine and were thereby subjected to tensile load until a plastic deformation was observed. Three samples were tested for each manufacturer and the average values were recorded.

\subsubsection{Compressive Strength}

Fifteen (15) numbers of $150 \times 150 \times 150$ cubes, representing the different five steel samples for $12 \mathrm{~mm}$ were cast and tested after 28 days of curing in accordance with [16]. Another set of 15 numbers, but for $16 \mathrm{~mm}$ steel bar were similarly cast and tested. The concrete mix ratio was 1: 2: 4 by weight, with the water/cement ratio of 0.5

\subsubsection{Bond Performance}

PVC pipe of diameter $300 \mathrm{~mm}$ and height $300 \mathrm{~mm}$ was used as mould for all specimens as shown in Figure 1. The reinforcement specimens were inserted up to $150 \mathrm{~mm}$ into the PVC pipe, and then filled with concrete. The top surface of the cylinder PVC pipe was then struck off with a trowel and covered with nylon to avoid evaporation near the surface of the protruding steel rod.

The PVC pipes were allowed to cure in a moist environment for 24 hours. The moulds were then removed and the concrete were cured in a curing tank containing clean water where they were kept until the $28^{\text {th }}$ day, the day for their testing. The curing water was left at room temperature. The 28th day pull out test was performed using AMSLER Hydraulic Machine. The yield and ultimate point were noted before the removal of the concrete from the machine. Average bond stresses were calculated using equation 3 , with diameter of the steel $\operatorname{rod}(12 \mathrm{~mm}$, and $16 \mathrm{~mm})$ and bonded length $(150 \mathrm{~mm})$.

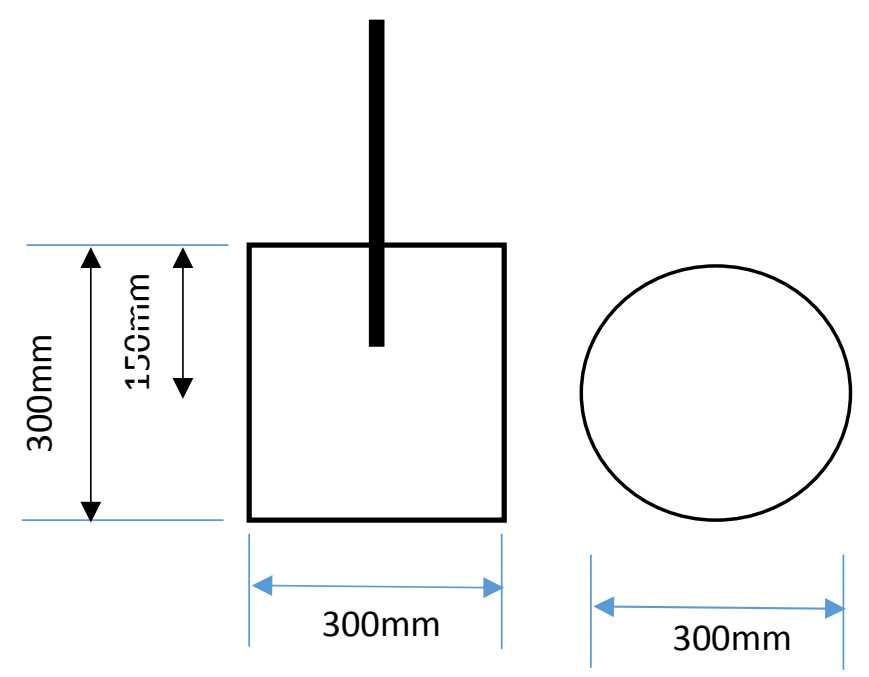

Figure 1: Arrangement of Pull out test for the Specimens

\section{RESULTS AND DISCUSSIONS \\ 3.1 Preliminary Results}

The tensile properties of the steel specimens tested are presented in Table 2 and Table 3, showing the yield stress, tensile strength and the elongation of the specimens. According to [17] a minimum strength of $460 \mathrm{~N} / \mathrm{mm}^{2}$ for high yield strength reinforcing steel is stipulated. From table 2, it can be observed that all steel specimens met the minimum requirements for $12 \mathrm{~mm}$ bars. Also [17] limits the minimum percent elongation after fracture to $12 \%$. Only the steel specimen marked $l_{3}$ did meet this requirement. All the specimens however satisfy the minimum stress ratio defined as the ratio of the tensile strength to the yield strength - , requirement of 1.05 .

The tensile properties for $16 \mathrm{~mm}$ diameter are shown in Table 3. It can be observed that all the specimens satisfied the minimum strength requirement of $460 \mathrm{~N} / \mathrm{mm}^{2}$ for high yield steel. Also all the steel specimens met minimum elongation requirement of $12 \%$, and all the steel specimens similarly satisfied the minimum stress ratio condition of 1.05 .

It can be concluded from the above values that all the steel specimens substantially met the minimum requirement specified by [17] for both $12 \mathrm{~mm}$ and 16 mm diameters.

In addition to the tensile properties, the average 28day compressive strength of the concrete used in the pull out tests as determined from $150 \times 150 \times 150 \mathrm{~mm}$ cubes was $28.7 \mathrm{~N} / \mathrm{mm}^{2}$. 
Table 2: Tensile properties (12mm bar)

\begin{tabular}{ccccccc}
\hline Tensile Properties & Diameter & \multicolumn{5}{c}{ Steel Manufacturer } \\
\cline { 3 - 7 } & $(\mathrm{mm})$ & $\mathrm{L}_{1}$ & $\mathrm{~L}_{2}$ & $\mathrm{~L}_{3}$ & $\mathrm{~F}_{1}$ & $\mathrm{~F}_{2}$ \\
\hline Yield Strength $\left(\mathrm{N} / \mathrm{mm}^{2}\right)$ & 12 & 491.16 & 470.93 & 459.38 & 586.50 & 496.94 \\
Tensile Strength $\left(\mathrm{N} / \mathrm{mm}^{2}\right.$ & 12 & 676.07 & 655.84 & 618.28 & 765.63 & 681.84 \\
\% Bar Elongation & 12 & 11.66 & 10.16 & 22.16 & 10.00 & 9.33 \\
Stress Ratio $\mathrm{R}_{\mathrm{m}} / \mathrm{R}_{\mathrm{e}}$ & 12 & 1.38 & 1.39 & 1.35 & 1.31 & 1.37 \\
\hline
\end{tabular}

Table 3: Tensile properties (16mm bar)

\begin{tabular}{lcccccc}
\hline Tensile Properties & Diameter $(\mathrm{mm})$ & \multicolumn{5}{c}{ Steel Manufacturer } \\
\cline { 3 - 7 } & & $\mathrm{L}_{1}$ & $\mathrm{~L}_{2}$ & $\mathrm{~L}_{3}$ & $\mathrm{~F}_{1}$ & $\mathrm{~F}_{2}$ \\
\hline Yield Strength $\left(\mathrm{N} / \mathrm{mm}^{2}\right)$ & 16 & 403.04 & 546.05 & 486.05 & 594.81 & 559.05 \\
Tensile Strength $\left(\mathrm{N} / \mathrm{mm}^{2}\right.$ & 16 & 559.05 & 680.94 & 604.56 & 721.57 & 687.44 \\
\% Bar Elongation & 16 & 21.83 & 13.83 & 17.33 & 15.16 & 13.33 \\
Stress Ratio $\mathrm{R}_{\mathrm{m}} / \mathrm{R}_{\mathrm{e}}$ & 16 & 1.39 & 1.25 & 1.24 & 1.21 & 1.23 \\
\hline
\end{tabular}

\subsection{Bond Characteristics}

The parameters investigated under bond strength are: yield and ultimate failure load, pull out length, and mode of failure.

\subsubsection{Yield and Ultimate Failure load}

Table 4 shows the yield and ultimate failure loads of three samples of each diameter used for the five different sources of reinforcement.

Table 4: The Yield and Failure Load of the Steel Specimens

\begin{tabular}{ccccc}
\hline & \multicolumn{2}{c}{$12 \mathrm{~mm}$ bar } & \multicolumn{2}{c}{$16 \mathrm{~mm}$ bar } \\
\cline { 2 - 5 } & $\begin{array}{l}\text { Yield } \\
\text { Load } \\
(\mathrm{KN})\end{array}$ & $\begin{array}{c}\text { Failure } \\
\text { Load }(\mathrm{KN})\end{array}$ & $\begin{array}{l}\text { Yield } \\
\text { Load } \\
(\mathrm{KN})\end{array}$ & $\begin{array}{c}\text { Failure } \\
\text { Load }(\mathrm{KN})\end{array}$ \\
\hline $\mathrm{L}_{1}$ & 52.63 & 69.66 & 64.10 & 74.23 \\
$\mathrm{~L}_{2}$ & 48.73 & 62.43 & 55.83 & 65.40 \\
$\mathrm{~L}_{3}$ & 32.70 & 41.90 & 32.70 & 40.53 \\
$\mathrm{~F}_{1}$ & 70.00 & 80.13 & 40.87 & 62.77 \\
$\mathrm{~F}_{2}$ & 61.47 & 67.03 & 51.70 & 66.07 \\
\hline
\end{tabular}

From the table, it can be observed that the yield loads for specimens $F_{1}$ and $F_{2}$ are significantly higher value than $\mathrm{L}_{1}, \mathrm{~L}_{2}$ and $\mathrm{L}_{3}$ for $12 \mathrm{~mm}$ diameter bar. However, $F_{1}$ and $L_{1}$ recorded higher failure loads. For $12 \mathrm{~mm}$ bar specimens, it is obvious that $\mathrm{F}_{1}$ has the highest yield and failure loads of $70 \mathrm{kN}$ and $80.13 \mathrm{KN}$ respectively. For $16 \mathrm{~mm}$ bar specimens, $\mathrm{L}_{1}$ has the highest yield and failure loads respectively of $64.10 \mathrm{KN}$ and $74.23 \mathrm{KN}$ of all the specimens tested.

\subsubsection{Bond Stress}

Figure 2 shows the average bond stress of all the bar specimens. It can be observed from the figure that 12 mm diameter bar specimens have higher bonding stresses than bar $16 \mathrm{~mm}$ for all the sample of reinforcements.

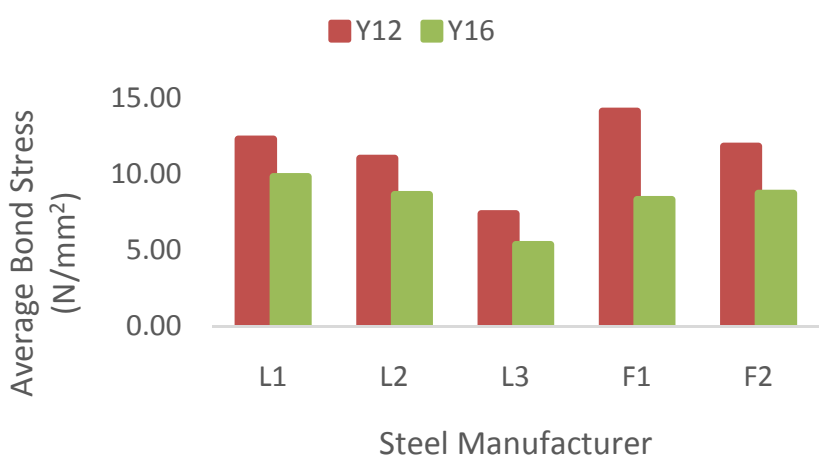

Figure 2: Average Bond Stress of the Steel specimens

This is obvious from equation 3 , where the stress is inversely proportional to the diameter of the steel, for a constant length as used in this investigation. It can also be seen that for $12 \mathrm{~mm}$ diameter bars, imported steel had a better bond performance than local ones. However, for $16 \mathrm{~mm}$ diameter bars, the bond performances of local ones were better than the imported ones. The theoretical average bond strengths for all the specimens were computed using equations 4 to 8 , and compared with the experimental result. This is shown in Table 5 and Table 6 respectively for $12 \mathrm{~mm}$ and $16 \mathrm{~mm}$ bar diameter. 
Table 5: Comparison between the Experimental and Theoretical Bond Stresses by different authors for 12 mm bar specimens

\begin{tabular}{|c|c|c|c|c|c|c|}
\hline \multirow{2}{*}{$\begin{array}{c}\text { Steel } \\
\text { Specimens }\end{array}$} & \multirow{2}{*}{$\begin{array}{c}\text { Average } \\
\text { Bond } \\
\text { Stress } \\
\left(\mathrm{N} / \mathrm{mm}^{2}\right) \\
\text { for this } \\
\text { Work }\end{array}$} & \multicolumn{5}{|c|}{$\begin{array}{l}\text { Theoretical Computations } \\
\qquad\left(\mathrm{N} / \mathrm{mm}^{2}\right)\end{array}$} \\
\hline & & [12] & [13] & {$[10]$} & [9] & [3] \\
\hline $\mathrm{L}_{1}$ & 12.31 & 30.2 & 2.14 & 23.9 & 30.7 & 12.1 \\
\hline $\mathrm{L}_{2}$ & 11.04 & 30.2 & 2.14 & 23.9 & 30.7 & 12.1 \\
\hline $\mathrm{L}_{3}$ & 7.40 & 30.2 & 2.14 & 23.9 & 30.7 & 12.1 \\
\hline$F_{1}$ & 14.16 & 30.2 & 2.14 & 23.9 & 30.7 & 12.1 \\
\hline $\mathrm{F}_{2}$ & 11.85 & 30.2 & 2.14 & 23.9 & 30.7 & 12.1 \\
\hline
\end{tabular}

For both $12 \mathrm{~mm}$ and $16 \mathrm{~mm}$ bar specimens, the results of the experimental values obtained from this work are relatively consistent with the work of [3]. All other mathematical expressions seem to overestimate or underestimate the bond stress. For example, the [13] underestimates the bond stress might be due to the fact the constant in the expression is not sufficient to compensate for the cumulative effects of: minimum concrete cover, bar diameter, and the embedded length in concrete, all of which are built in into [3] expression.

Although the expression from [3] is similar in structure to [9], the obvious difference in the values of the bond stress between the two may be as a result differences in the coefficients of the two expressions. The same reason applies to [10]. The fact that [12] did not take into account the embedded length may also be a reason for the disparity.

\subsubsection{Pull out length and Slippage}

The slippage, of all the bar specimens for $12 \mathrm{~mm}$ and $16 \mathrm{~mm}$ diameter bars are shown in Figures 3 and 4 . Slip occurs and bond strength reduces when adhesion between steel and concrete is broken on the application of load to a structural member.

It can be observed in the figures that the lowest values of slippage were exhibited by steel specimens $\mathrm{L}_{3}$ for both $12 \mathrm{~mm}$ and $16 \mathrm{~mm}$ diameter bars. This may suggest that $\mathrm{L}_{3}$ has a coarser surface, thus enabling it to generate a higher frictional force between it and the surrounding concrete than all other steel specimens used in this investigation. Also the lowest slip of steel specimen $\mathrm{L}_{3}$ suggests a very strong chemical adhesion between the cement paste and the bar.
$12 \mathrm{~mm}$ bar specimens

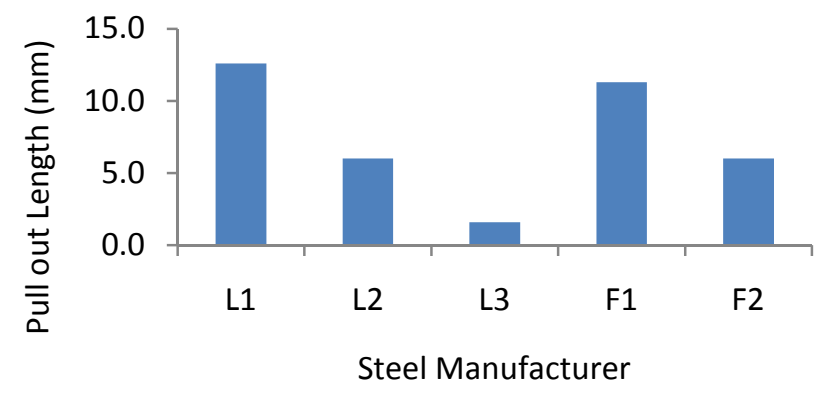

Figure 3: Slippage for $12 \mathrm{~mm}$ diameter for all the steel specimens

$16 \mathrm{~mm}$ bar specimens

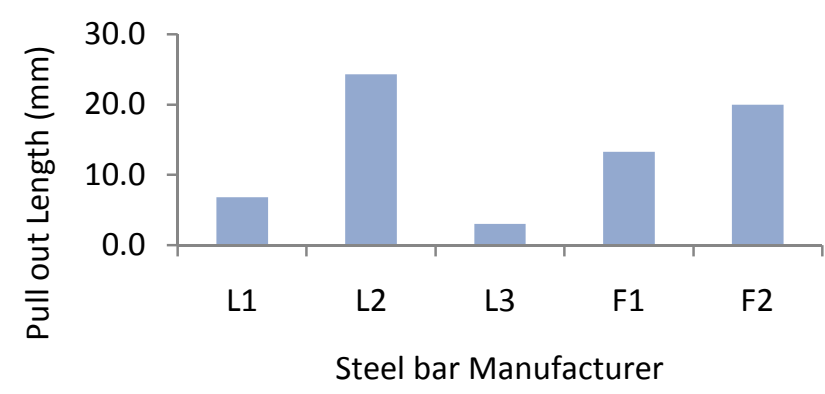

Figure 4: Slippage for $16 \mathrm{~mm}$ diameter for all the steel specimens

\subsubsection{Mode of failure}

The failure pattern exhibited by the steel specimens during investigation via pull out tests is predominantly splitting failure for all the tested specimens, irrespective of their source. Typical pictures are shown in Figures 5.

The splitting failure mode occurred when the concrete cover failed to provide adequate confinement [3]. It was characterized by splitting of the concrete specimens in a brittle mode of failure. Both transverse and longitudinal cracks were observed at failure. Further, [3] explains that as the cracks materialized, the bond forces were directed outward from the bar surface and these forces caused anchorage failure by splitting off the confining concrete. What this results suggest is the need for designers to provide adequate cover to reinforcement as a way to prevent splitting failure. 
Table 6: Comparison between the Experimental and Theoretical Bond Stresses by different authors for 16 mm

\begin{tabular}{ccccccc}
\multicolumn{3}{c}{ bar specimens } \\
\hline Steel Specimens & Average Bond Stress $\left(\mathrm{N} / \mathrm{mm}^{2}\right)$ for this Work & \multicolumn{4}{c}{ Theoretical Computations $\left(\mathrm{N} / \mathrm{mm}^{2}\right)$} \\
\cline { 3 - 7 } & & {$[12]$} & {$[13]$} & {$[10]$} & {$[9]$} & {$[3]$} \\
\hline $\mathrm{L}_{1}$ & 9.84 & 21.3 & 2.14 & 19.7 & 23.5 & 11.80 \\
$\mathrm{~L}_{2}$ & 8.67 & 21.3 & 2.14 & 19.7 & 23.5 & 11.80 \\
$\mathrm{~L}_{3}$ & 5.38 & 21.3 & 2.14 & 19.7 & 23.5 & 11.80 \\
$\mathrm{~F}_{1}$ & 8.32 & 21.3 & 2.14 & 19.7 & 23.5 & 11.80 \\
$\mathrm{~F}_{2}$ & 8.76 & 21.3 & 2.14 & 19.7 & 23.5 & 11.80 \\
\hline
\end{tabular}

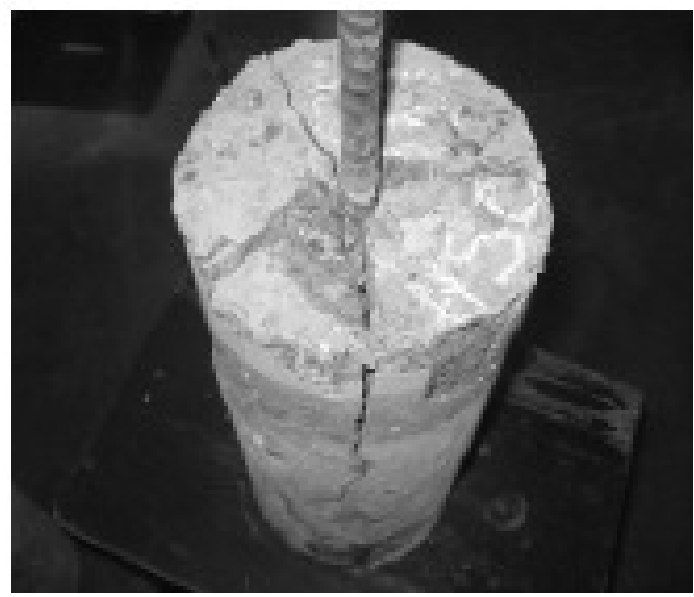

a) Splitting failure of Imported Specimens

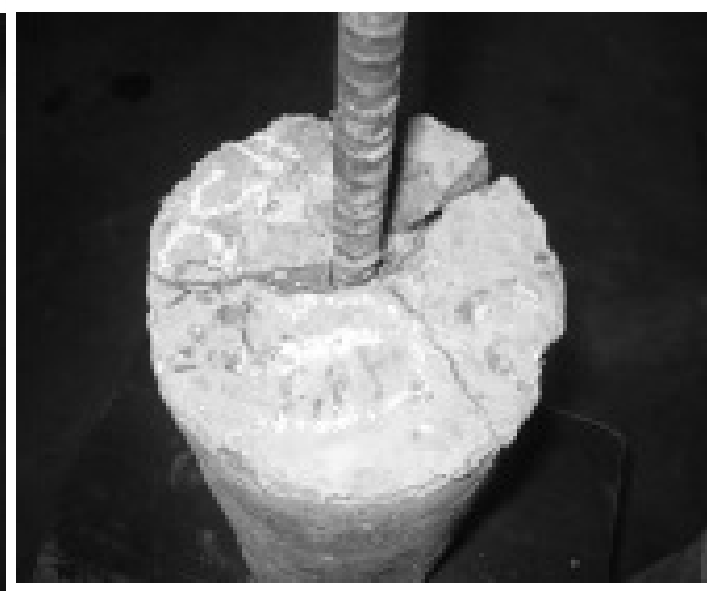

a) Splitting failure of Local Specimens

Figure 5: The Typical Failure Modes of the Steel Specimens

\section{CONCLUSIONS}

Based on the bonding experiments with concrete containing imported and locally sourced reinforcement as reinforcing bars, the following observations and conclusions can be made on the basis of the current experimental results:

1) It can be concluded from the above values that all the steel specimens substantially met the minimum requirement specified by [17] for both $12 \mathrm{~mm}$ and $16 \mathrm{~mm}$ diameters.

2) Bond performance of locally-made was found to be better than the imported ones for $12 \mathrm{~mm}$ diameter, but for $16 \mathrm{~mm}$ diameter, imported steel showed a better bond performance than the locally made ones.

3) The bond stress obtained from this investigation agreed with the expression developed by [3] for both $12 \mathrm{~mm}$ and $16 \mathrm{~mm}$ diameter bars.

4) It can be observed in the figures that the lowest values of slippage were exhibited by steel specimens $\mathrm{L}_{3}$ for both $12 \mathrm{~mm}$ and $16 \mathrm{~mm}$ diameter bars.

5) All the steel specimens exhibited splitting failure.

\section{REFERENCES}

[1] Torre-Casanova. A, Jason. L, Davenne. L, Pinelli. X. (2013). "Confinement Effects On The Steel-Concrete Bond Strength And Pull-Out Failure". Engineering Fracture Mechanics, Vol. 97, pp. 92-104.

[2] Warner R. F., Rangan B. V., Hall A. S., Faulkes K. A., (1998) "Concrete Structures", Longman, Australia, 1998.

[3] Hadi, Muhammad N.S (2008). "Bond of High Strength Concrete with High Strength Reinforcing Steel”. The Open Civil Engineering Journal, Vol. 2, pp. 143-147.

[4] De Larrard, F., Scahaller, I. and Fuchs, J. (1993), "Effect Of Bar Diameter On The Bond Strength of Passive Reinforcement In High-Performance Concrete", ACI Materials Journa,l Vol. 90, No. 4, pp.333 - 339.

[5] Tang W.C, Lo T.Y. Balendran R.V. (2008) "Bond Performance Of Polystyrene Aggregate Concrete (PAC) Reinforced With Glass-Fibre-Reinforced Polymer (GFRP) Bars". Building and Environment Vol. 43, pp. 98-107

[6] Sharma S.K, Mohamed Ali M.S, Goldar D, Sikdar P.K (2006). "Plate-Concrete Interfacial Bond Strength Of FRP And Metallic Plated Concrete Specimens". Composites Part B: Eng. Vol. 37, No. 1, pp. 54-63. 
[7] Yao J, Tang J.G, Chen J.F. (2005). “Experimental Study On FRP-To-Concrete Bonded Joints". Composites Part B: Eng Vol. 36, No. 2, pp. 99 - 113.

[8] Abrishami H. H. and Mitchell D. (1992) "Simulation of Uniform Bond Stress", ACI Materials Journal, Vol. 89, No. 2, pp. 161-168.

[9] Orangun, C. O., Jirsa, I. O. and Breen, J. E. (1977) “A Reevaluation of Test Data on Development Length and Splices". ACI Materials Journal, Vol. 74, No. 3, pp. 114-122.

[10] Darwin, D., McCabe, S. L., Idun, E. K. and Schoenekase, S. P. (1992) "Development Length Criteria: Bars Not Confined by Transverse Reinforcement", ACI Structural Journal, Vol. 89, No. 6, pp. 709-720

[11] Esfahani, M. R. and Rangan, B. V. (1998) "Bond Between Normal Strength and High-Strength Concrete (HSC) and Reinforcing Bars in Splices in
Beams", ACI Structural Journal, Vol. 95, No. 3, pp. 272 $-280$.

[12] AS 3600 (1994) "Australian Standard for Concrete Structures". North Sydney, Australia

[13] BS 8110 (1997) "Structural Use of Concrete - Part I: Code of Practice for Design and Construction". British Standard Institution, London.

[14] BS 12 (1996). "Specification for Portland Cement". British Standard Institution, London.

[15] NIS - 444 (2003) "Standard for Cement". Standard Organization of Nigeria, Lagos.

[16] BS EN 12390-3 (2009). “Testing Hardened Concrete: Compressive Strength of Test Specimens". British Standard Institution, London.

[17] BS 4449 (1997) "Carbon Steel Bars for the Reinforcement of Concrete". British Standard Institutions, London. 